\title{
Identifying Historical Paper Fibers to Dating Feasibility of Unknown Samples
}

\author{
Masoud B. Kasiri ${ }^{* 1}$, Bahareh Younesi ${ }^{2}$, Afsaneh Yajam ${ }^{3}$ \\ ${ }^{1}$ Associate Professor, Department of Archaeometry, Faculty of Applied Arts, Tabriz Islamic Art \\ University, Tabriz, IRAN \\ ${ }^{2}$ M.A. Department of Archaeometry, Faculty of Applied Arts, Tabriz Islamic Art University, Tabriz, IRAN \\ ${ }^{3}$ M.A. The Field of Conservation of Historic-Cultural Properties, Tabriz Central Public Library, IRAN
}

\begin{abstract}
Historical papers with all museum and aesthetic value have considerable cultural and scientific importance which represents how societies were during history improved. Studying historical papers is a way to discover the changes of human's life in different cases such as economics, culture and politics. Between existing manuscripts prescriptions there are some, which are left unseen unfortunately due to lack of recognition of their writing date. So to understand their originality, we require technical and structural analyses. Quantitative and qualitative methods of analysis and identification of organic paper are able to recognize their structure and thus the probable time of the paper making process or use it as a cultural work. Today, using scientifically exact methods like radiocarbon dating of organic material such as dating paper results well. Unfortunately, it is impossible to use this method in our country because of high cost and lack of access for most of experts. In this research we seek to know the most used materials in a specific era and to make possible the indirect dating by studying and recognizing fibers and sizing in historical papers. We have used microscopic observations, color reagents and Fourier Transform Infrared Spectroscopy (FT-IR) methods. Results showed that linen, and hemp fibers have a high level of application in studied dated manuscripts and there is conformity in these results with results of studied undated ones.
\end{abstract}

Keywords: Dating, manuscripts, Identify fibers, Colored reagents, FT-IR.

*Corresponding author: m.kasiri@tabriziau.ac.ir 


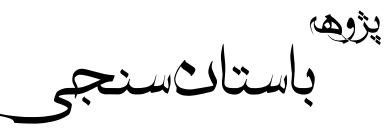

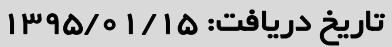

مقاله يزّوهشى

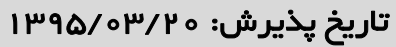

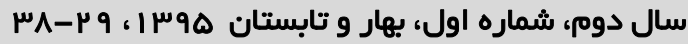

\section{شناسايى الياف كاغذهاى تاريخى جهت امكانسنجى تاريخَذارى

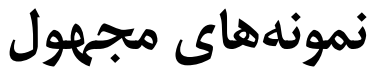

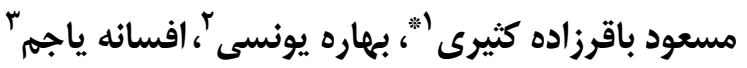

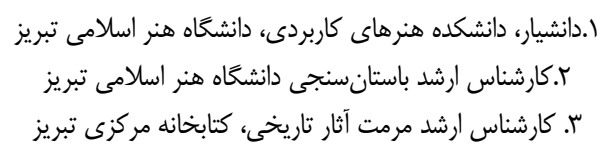

إ. إنشيار، دانشكده هنرهاى كاربردى، دانشكاه هنر اسلامى تبريز

r.كارشناس ارشد باستان سنجى دانشخاه هنر اسلامى تبريز

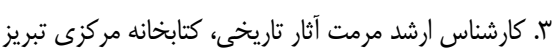

جִكيده

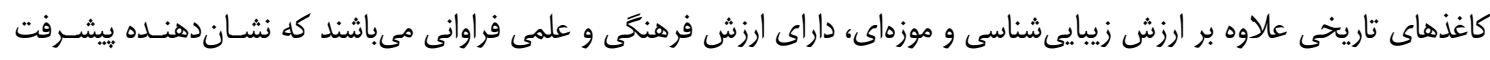

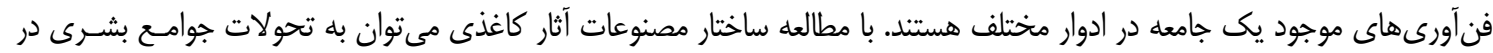

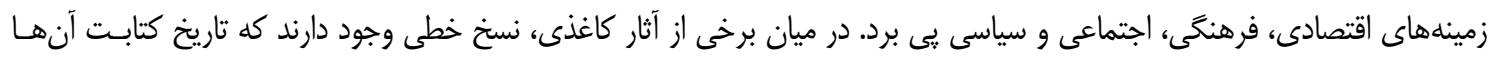

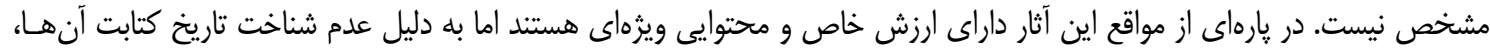

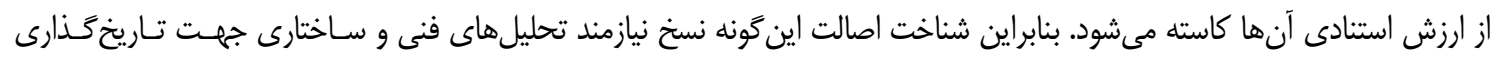

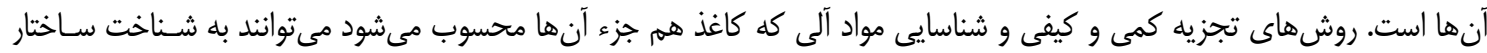

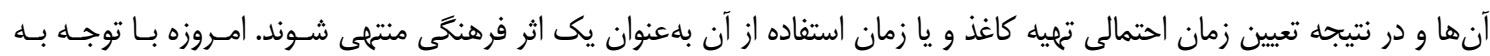

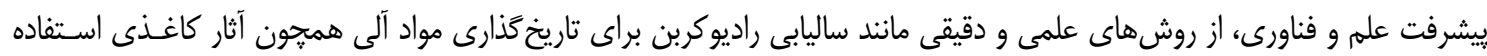

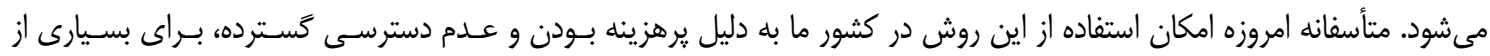

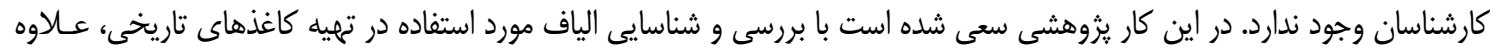

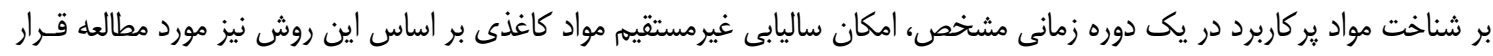

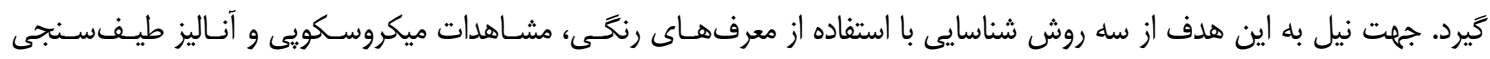

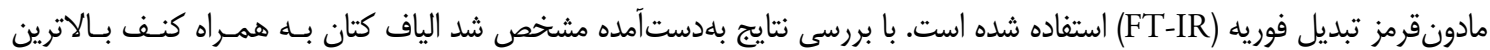

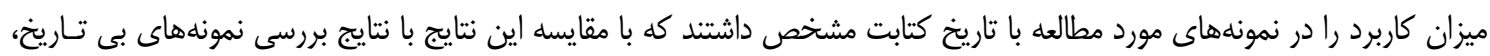
همخوانى خوبى مشاهده شد.

وازًَان كليدى: تاريخذارى، نسخ خطى، شناسايى الياف، معرفهاى رنكى، FT-IR

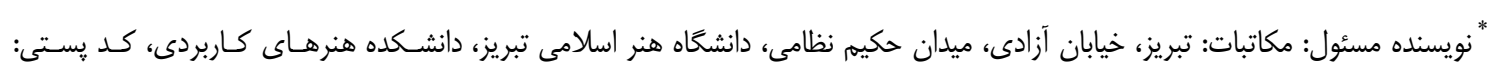

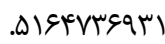

m.kasiri@tabriziau.ac.ir : يست الكترونى

(C) حق نشر متعلق به نويسنده(كان) است و نويسنده تحت مجوز Creative Commons Attribution License به مجله اجازه مى دهد مقاله خاب شده را با ديخران به اشتراك بحذارد منوط بر اينكه حقوق مؤلف اثر حفظ و به انت انتشار اوليه مقاله در اين مجله اشاره شود. 
يرداختهاند. در اين بين، مطالعات مختلفى بر روى اليـاف

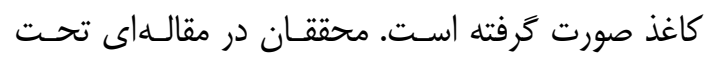

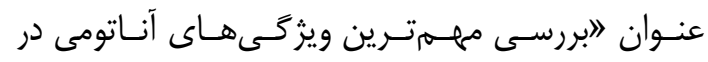

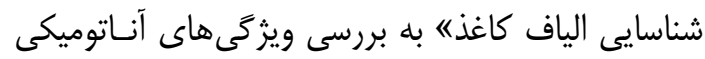

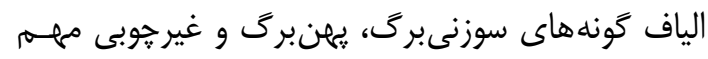

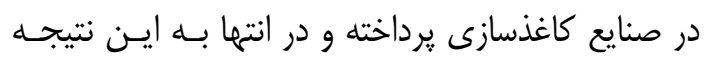
رسيدهاند كه شناسايى اليـاف كاغـذ امكـانيـذير اسـتـ

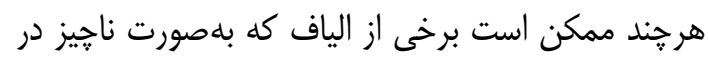

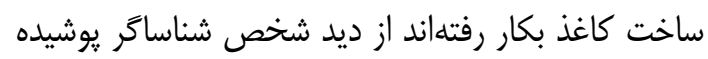

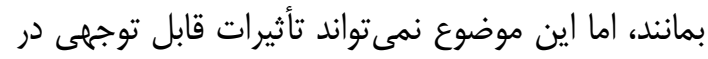

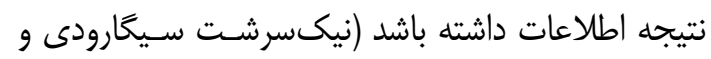

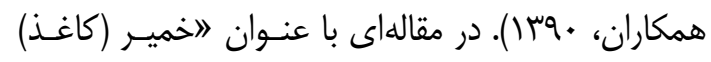

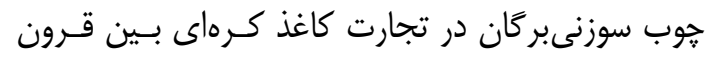

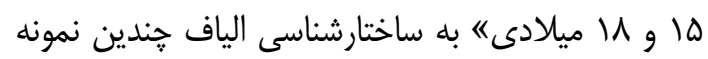

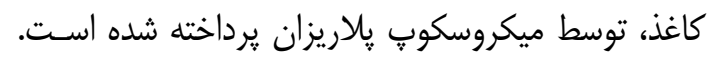

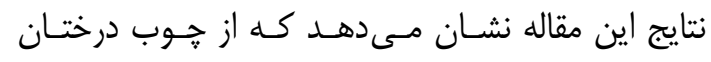
بلهعنوان تركيبى از خمير در كاغذسازى سنتى شبهجزيره

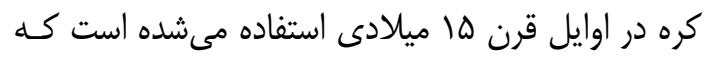

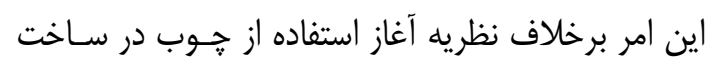
كاغذ در غرب است. همجنين، نتايج آناليزها تأكيد داشته

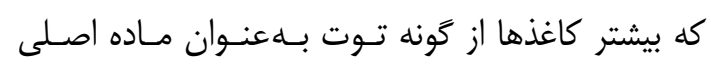

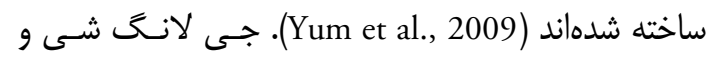

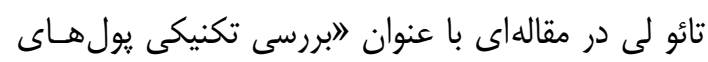
كاغذى رايج جين در قرون ها و و 19: الياف مورد استفاده

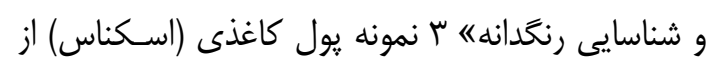

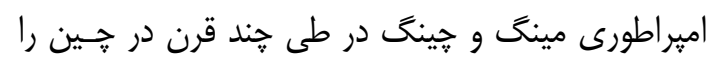

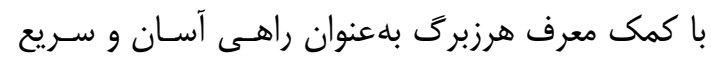

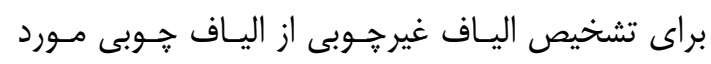

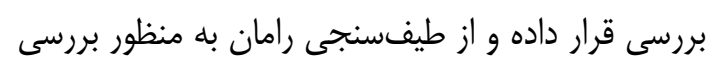

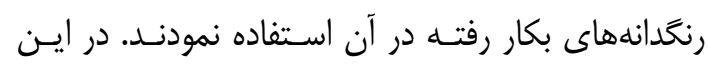

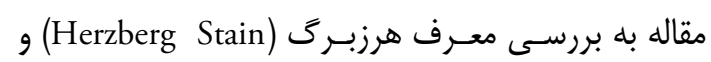

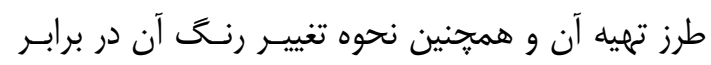

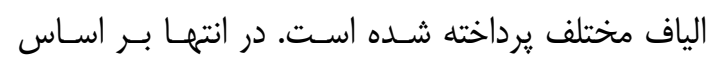

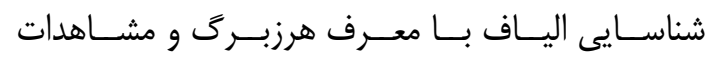

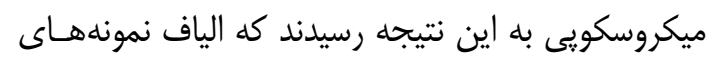

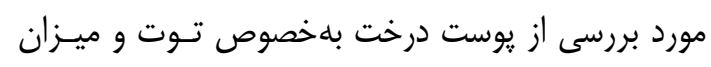

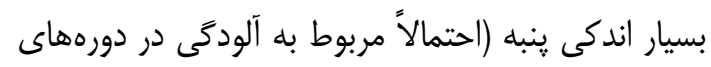

| - - (- مقدمه

هر نسخه خطى ييشينهاى دارد كه بررسى و تبيـين ايـن

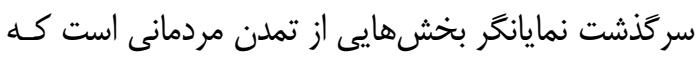

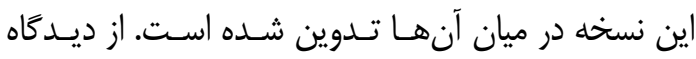

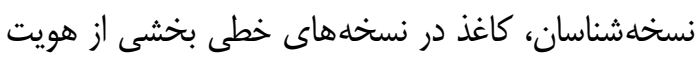

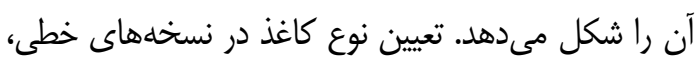

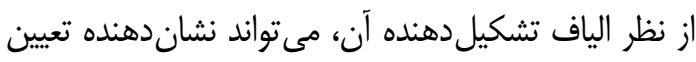

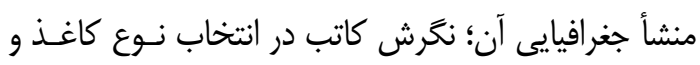

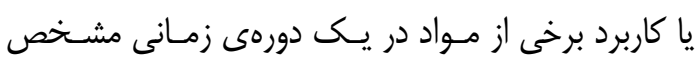

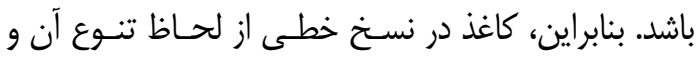

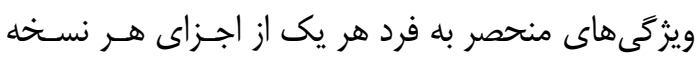

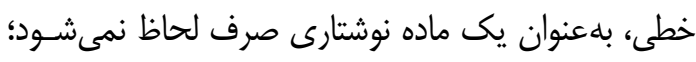

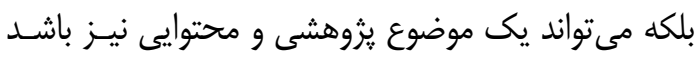

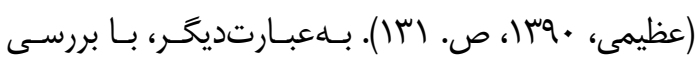

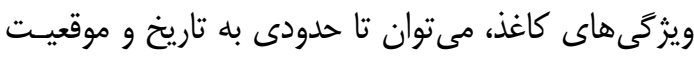

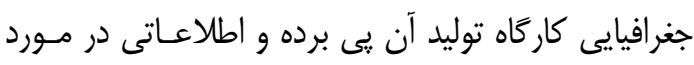

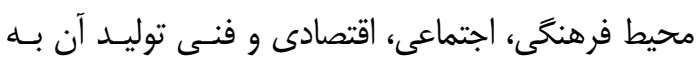

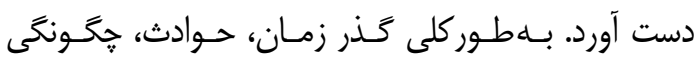

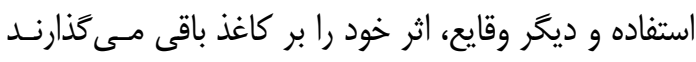

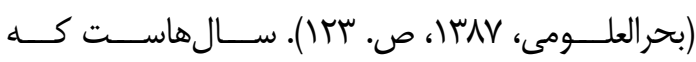
كارشناسان و نسخه شناسان براى طبقهبندى نسخ خطى صلى

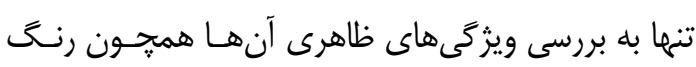

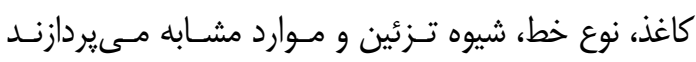

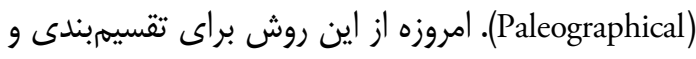

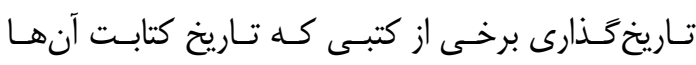

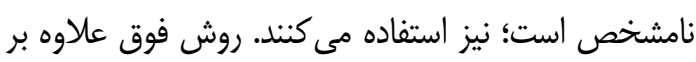

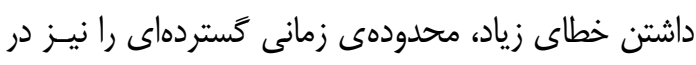

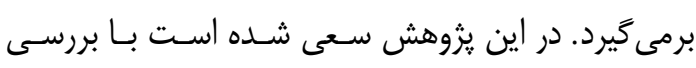

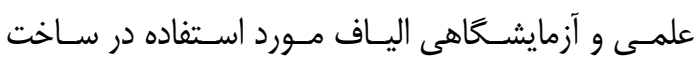
كاغذهاى تاريخى با تاريخ كتابت معلوم و نـامعلوم، عـالاوه

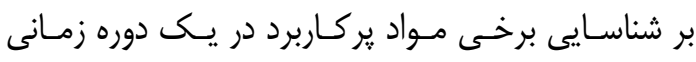

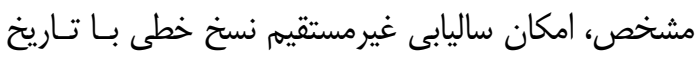
كتابت نامعلوم مورد بررسى قرار گيردان

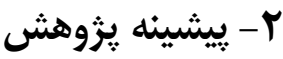

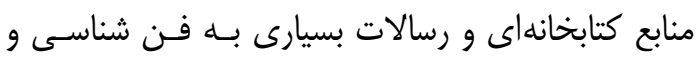

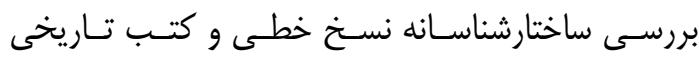

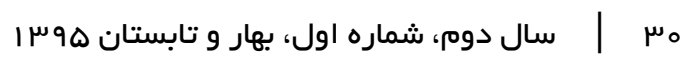


ساخت كثور زاين و ميكروسكوب پِالاريـزان Jasco 2002

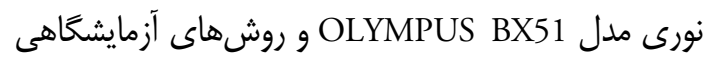
شيمى كلاسيك، الياف و آهار نمونههاى كاغذ تـاريخى در

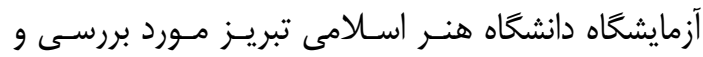

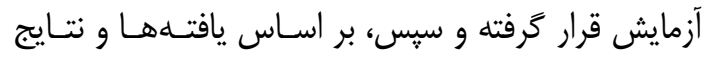

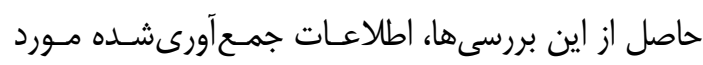
تحليل و تفسير قرار گرفتند. در مراحل مختلف تحقيـق، از

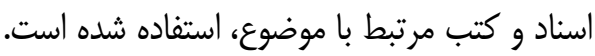

\section{ץ- نمونههاى مورد مطالعه، دستخاهها و روش اجراي آزمايشها}

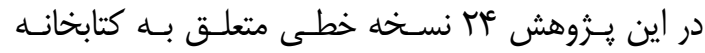

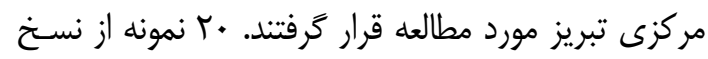

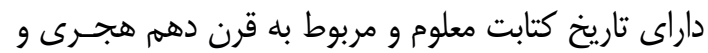

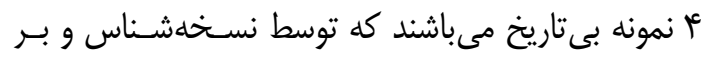

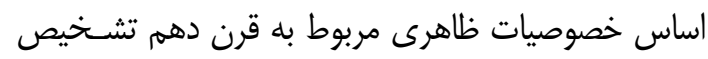

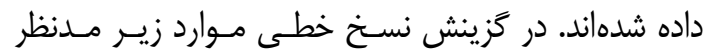
بودند:

1. تمام نمونهها بـا تـاريخ معلـوم مربـوط بـهـ قـرن

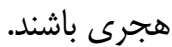
تاريخ دقيق كتابت توسط كاتـب در انتهـاى نسـخه

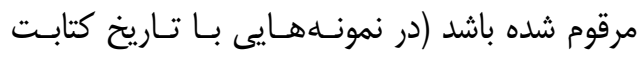

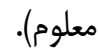

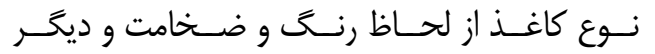
ويزگى هاى ظاهرى در تمامى صفحات نسخه شـبيه و يكسان باشد.

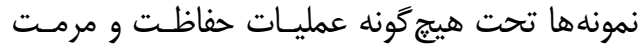
قرار نخرفته باشند. صفحات نسخ، رنخى و يا داراى تصوير نباشند.

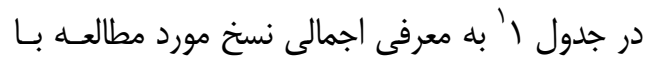
تاريخ كتابت مشخص و نامشخص يرداختـه شـــه اسـت. عنوان انتخاب شده براى نام كذارى نمونهها همان شـماره ترابت

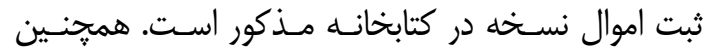

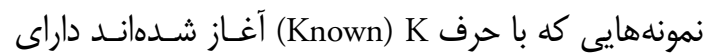

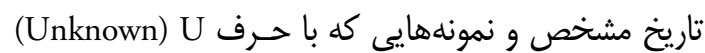
آغاز شدند، احتمالاً مربوط به قرن دهم نهم هستند.
بعدتر است) مىباشند و نه اليافى مانند بامبو، بـرنج و يـاــا

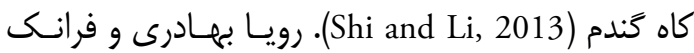

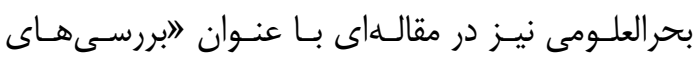

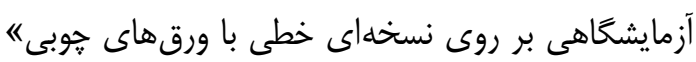

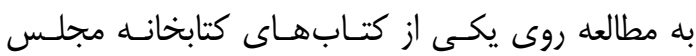

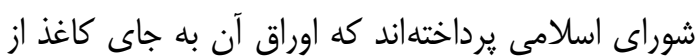

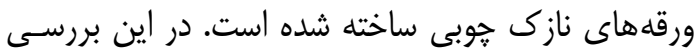
از سه دستخاه طيفسنج مادون قرمز تبديل فوريـهـ (FT)

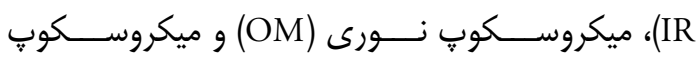

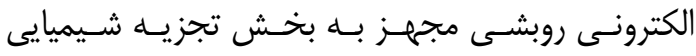
يراكندكى انرزى يرتوايكس (SEM -EDX) استفاده شده

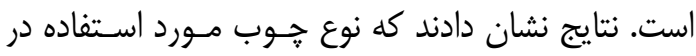

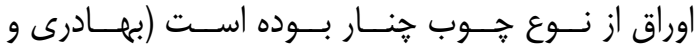

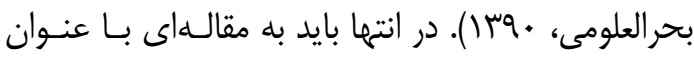
"اهم شكل هاى كتان: مشكلات شناسايى الياف كيـاهى

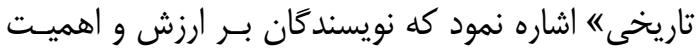

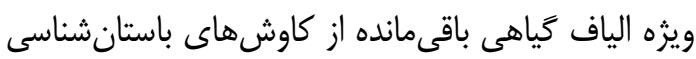

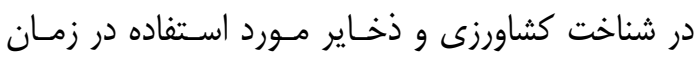

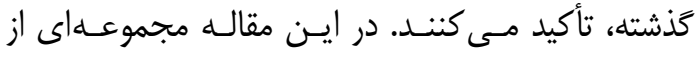

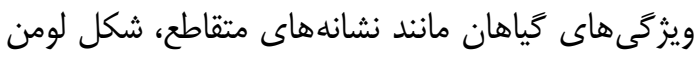

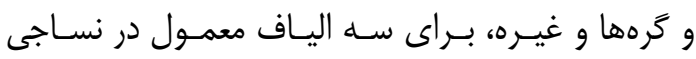

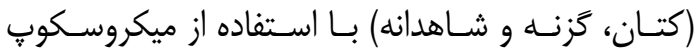

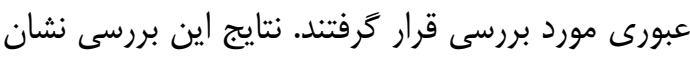

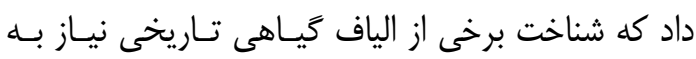
بررسى و مطالعات زيادى داشته و ممكن است برخسى از از

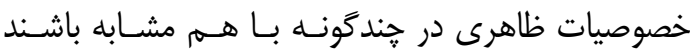

.(Haugan and Holst, 2013)

\section{r- روش تحقيق}

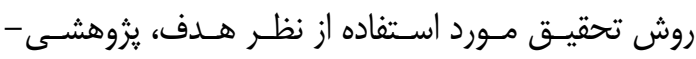

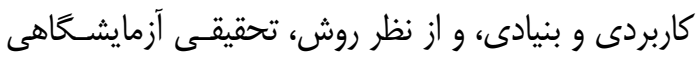

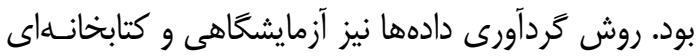

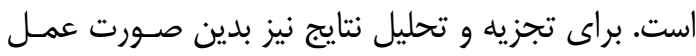

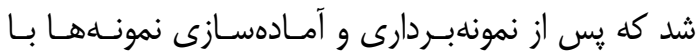

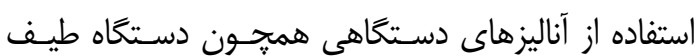

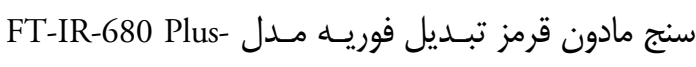


جدول (: مشخصات نسخ مورد مطالعه (يونسى، سوسا، ص. (F)

\begin{tabular}{|c|c|c|c|}
\hline تاريخ كتابت & نويسنده & عنوان اصلى & شماره \\
\hline ( & شهيد ثانى، زينالدينبن على، (9) -999 ق. & حاشيه بر شرايع الاسلام & K818 \\
\hline r99هـ & سلطان محمدبن اميرى & 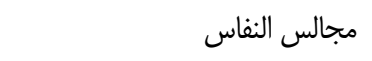 & K597 \\
\hline 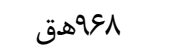 & 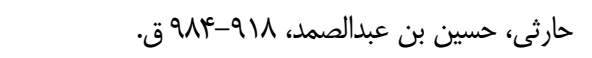 & رسائل عزالدين عاملى & K651 \\
\hline 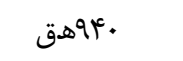 & 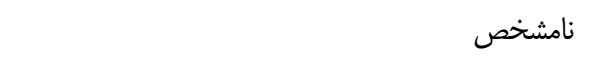 & قرائت عبداله بن كثير & K697 \\
\hline T T99هق & دوانى، محمدبن اسعد، •rی-^•^ ق. & شواكل الحور فى شرح هياكل النور & K1144 \\
\hline 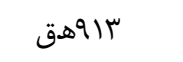 & ابن بيطار، عبدالله بن احمد، وعز ق. & كتاب الجوامع القوى الادويه & K1174 \\
\hline זTهـق & سرورى & شرح شبستان خيال & K1432 \\
\hline 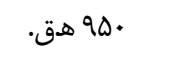 & نشاطى، محمدبن حسين الكاتب & ترجمه صفوه الصفا & K1872 \\
\hline 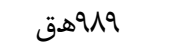 & 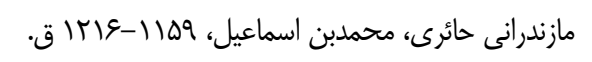 & منتهى المقال & K1927 \\
\hline (909 & اميرعليشيرنوائى، عليشيربن كيجكنه، عَ^-؟.9 ق.؟ & ديوان امير عليشير نوائى & K123 \\
\hline \multirow[t]{2}{*}{ 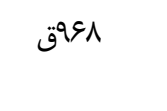 } & بدليسى، ادريس بن حسامالدين، • •به ق. & هشت بهشت & K1874 \\
\hline & & مجموعه (حليه حلل و ...) & K1672 \\
\hline 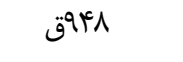 & جامى، عبدالرحمن بن احمد ، NIV - 191 ق. & تحفd الاسرار ت & K156 \\
\hline 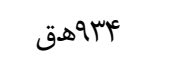 & علامه حلى، حسن بن يوسف، ب؟ - - YY ق. & تحرير الاحكام & K821 \\
\hline Trاهـ & 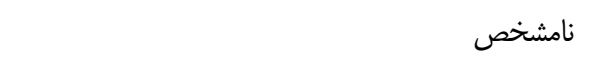 & 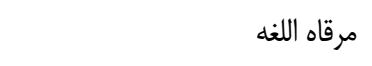 & K1641 \\
\hline 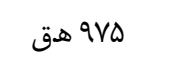 & سعدى، مصلحبن عبدالله، ا99 ق.؟ & 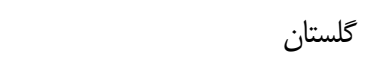 & K534 \\
\hline 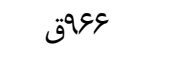 & خوارزمى، عليشاه بن محمدقاسم معروف به علاء بخارى & اشجار و اثمار & K1358 \\
\hline قqทe & ابن جزله , يحيى بن عيسى سوףא ق. & منهاج البيان فيما يستعلمه الانسان & K1179 \\
\hline قave & بيضاوى، عبدالله بن عمر، هAه ق. & انوار التنزيل و اسرار التاويل & K572 \\
\hline 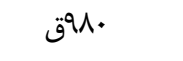 & جامى، عبدالرحمن بن احمد ، & 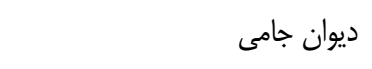 & K236 \\
\hline احتمالا قرن · 1 & 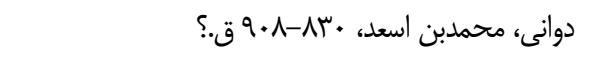 & 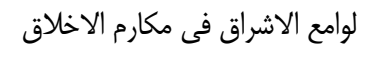 & U1522 \\
\hline احتمالا قرن ·1 & شيخ احمد الهى & 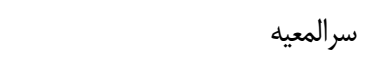 & U1497 \\
\hline احتمالا قرن · ا & 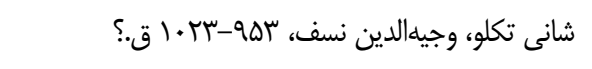 & ديوان شانى & U1359 \\
\hline احتمالا قرن • & 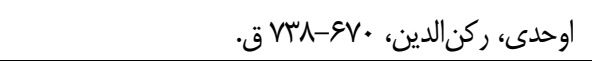 & 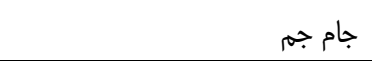 & U1389 \\
\hline
\end{tabular}

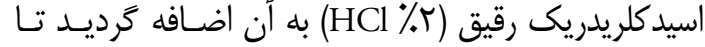

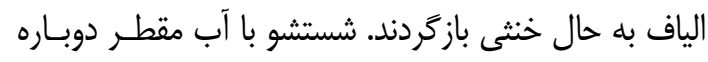
تكرار مىشد و پِ از آماده شدن نمونه براى جداسازى، از

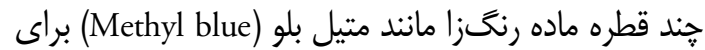

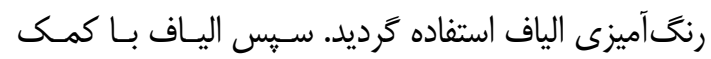

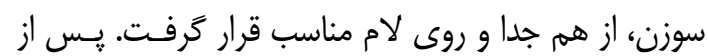

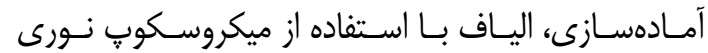

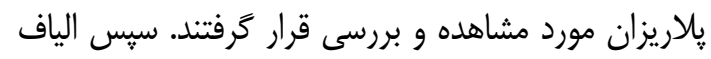

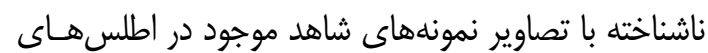

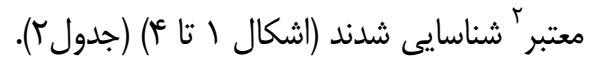

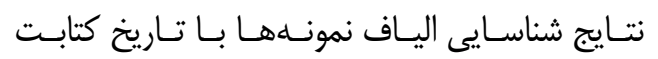
مشخص در شكل ه آمده است. همجنين شكل 9 مربـوط به نتايج شناسايى الياف نمونههاى فاقد تاريخ است.

\section{ه- شناسايى با استفاده از ميكروسكوب نورى يلاريزان}

آمادهسازى نمونهها و تهيه لامهاى ميكروسـكويى جهـت شناسايى الياف بـر اسـاس اسـتاندارد - TAPPI(T 401om

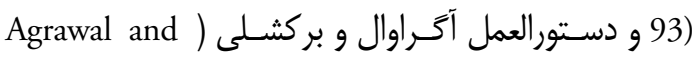
Barkeshli, 1997 انجام گرفت. بر اين اساس، تكه بسـيار

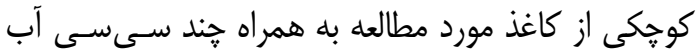
مقطر حرارت داده شد. اين كار تا زمانى كه الياف كاغذ بــهـ

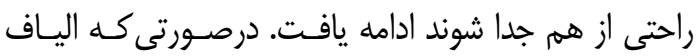

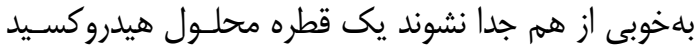
سديم ( (NaOH ) به آن اضافه و كر مـادهى مسى شـود. سبِ الياف با آب مقطـر خُنـد مرتبـه شسـته شـده و در

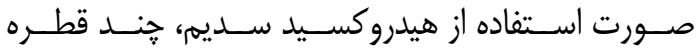

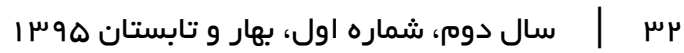




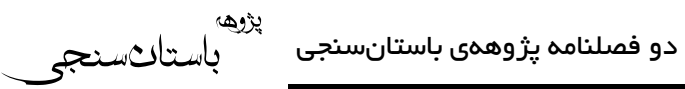

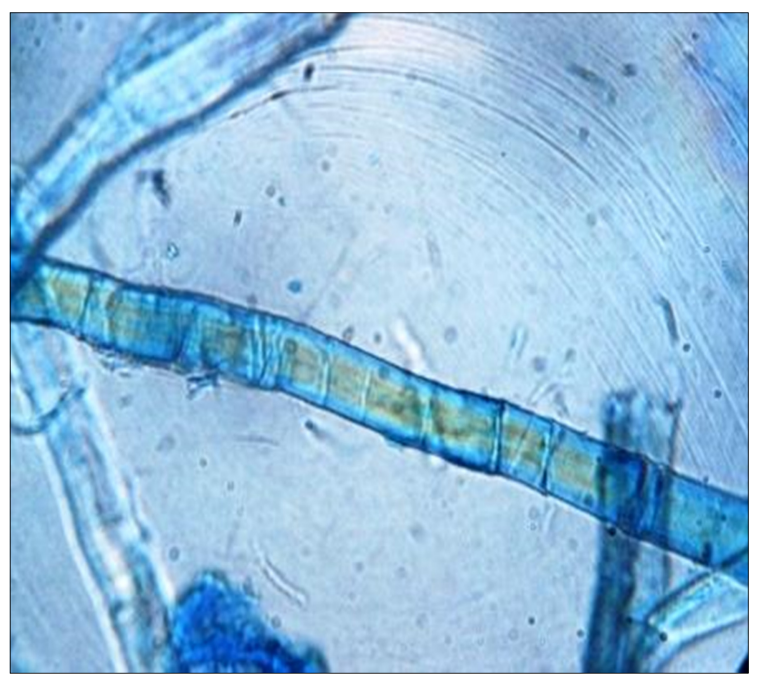

شكل ז: ليف كتان با بزركنمايى •• ب برابر

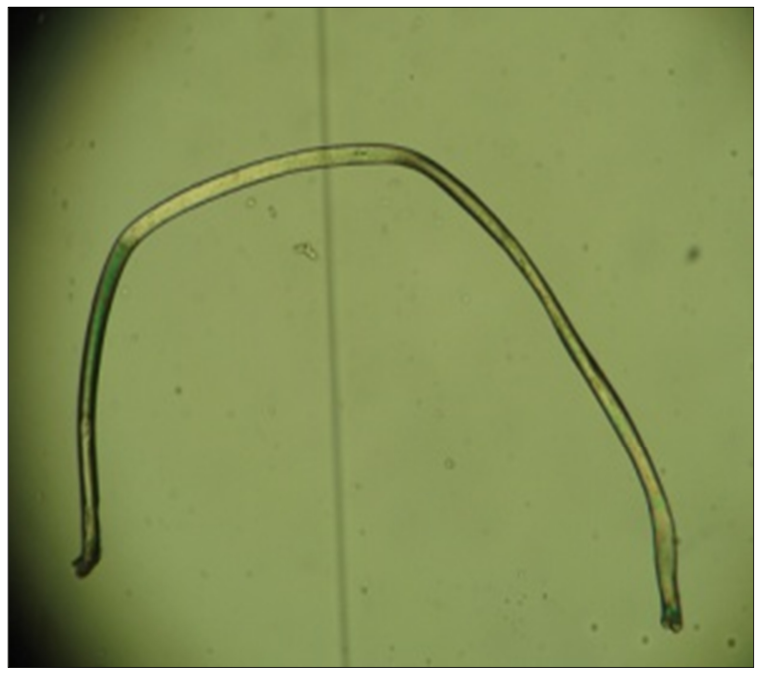

شكل f: ليف ابريشم با بزر كنمايى ..1 برابر

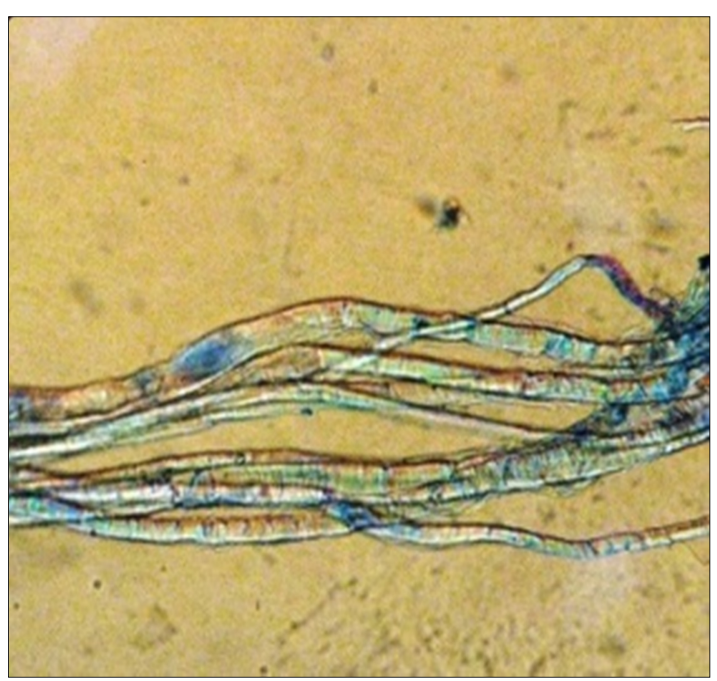

شكل (: الياف كنف با بزركنمايى .. ب برابر

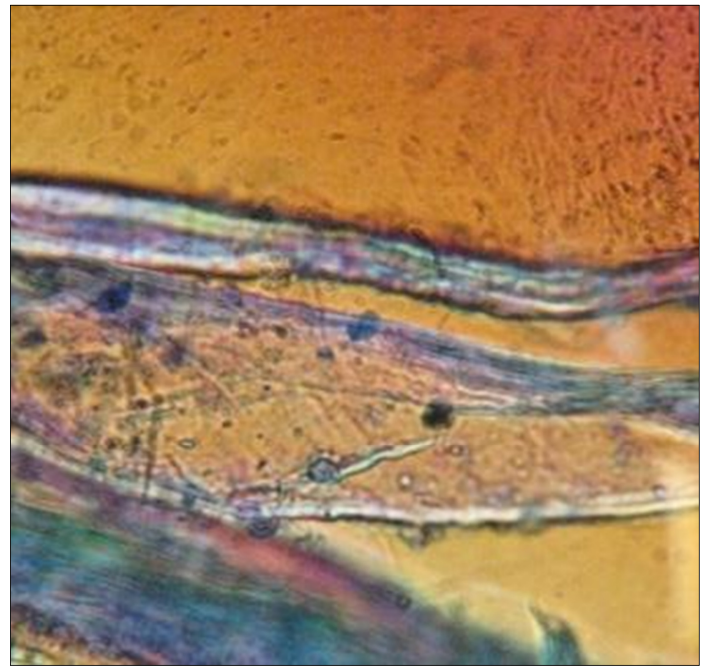

شكل ": الياف ينبه با بزركنمايى ... (1 برابر

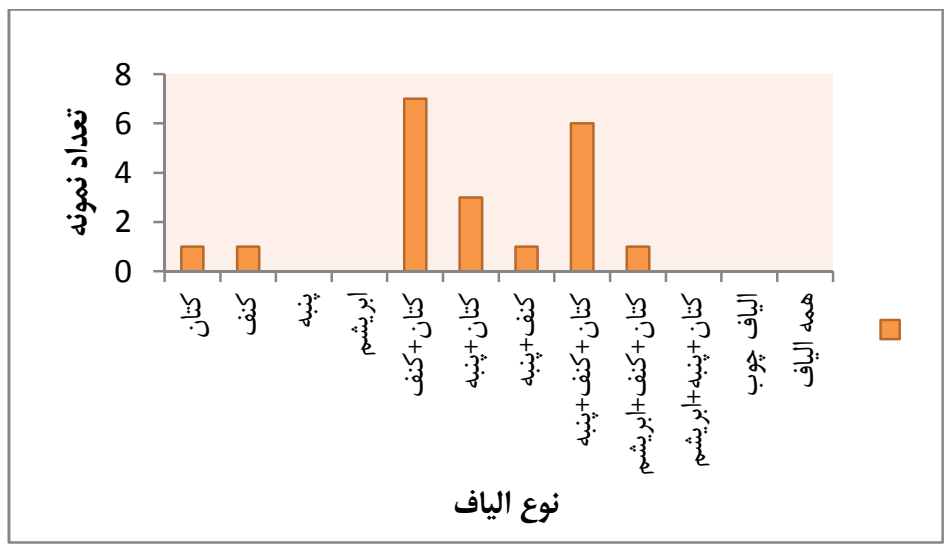

شكل ه: نمودار نتايج بهدستآمده از مطالعهى ميكروسكويى الياف نسخ با كتابت معلوم

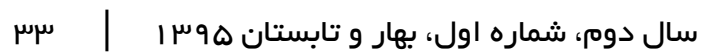


جدول ז: نتايج شناسايى ميكروسكوبى الياف نمونها (يونسى، بوسا، ص. V9)

\begin{tabular}{|c|c|c|c|c|}
\hline موارد ديكر & بِنبه & كنف & كتان & شماره \\
\hline ندارد & - & + & - & $\mathrm{K} 818$ \\
\hline ندارد & - & + & + & K676 \\
\hline 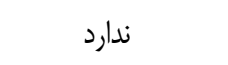 & + & + & - & K597 \\
\hline ندارد & + & + & + & K1041 \\
\hline احتمالا برى درخت & - & - & + & K1432 \\
\hline ندارد & + & + & + & K1872 \\
\hline 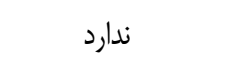 & - & + & + & K1144 \\
\hline ندارد & + & + & + & K413 \\
\hline ندارد & - & + & + & K1927 \\
\hline 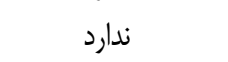 & - & + & + & K1980 \\
\hline ندارد & - & + & + & K651 \\
\hline ن ندارد & - & + & + & K123 \\
\hline 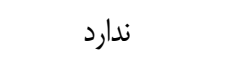 & + & + & - & K1672 \\
\hline 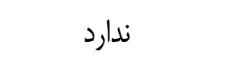 & + & + & + & K156 \\
\hline 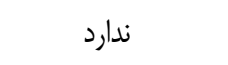 & + & - & + & K1134 \\
\hline 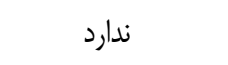 & + & - & + & K534 \\
\hline ابريشم & + & + & + & K1212 \\
\hline 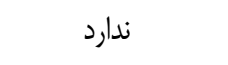 & + & + & + & K1358 \\
\hline 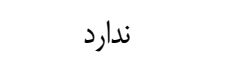 & - & + & + & K1179 \\
\hline 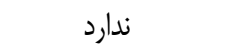 & + & + & + & K236 \\
\hline 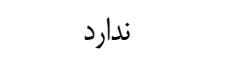 & + & + & + & U1522 \\
\hline 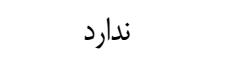 & - & - & + & U1497 \\
\hline 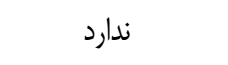 & + & + & + & U1476 \\
\hline 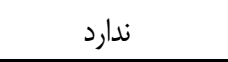 & + & - & + & U1359 \\
\hline
\end{tabular}

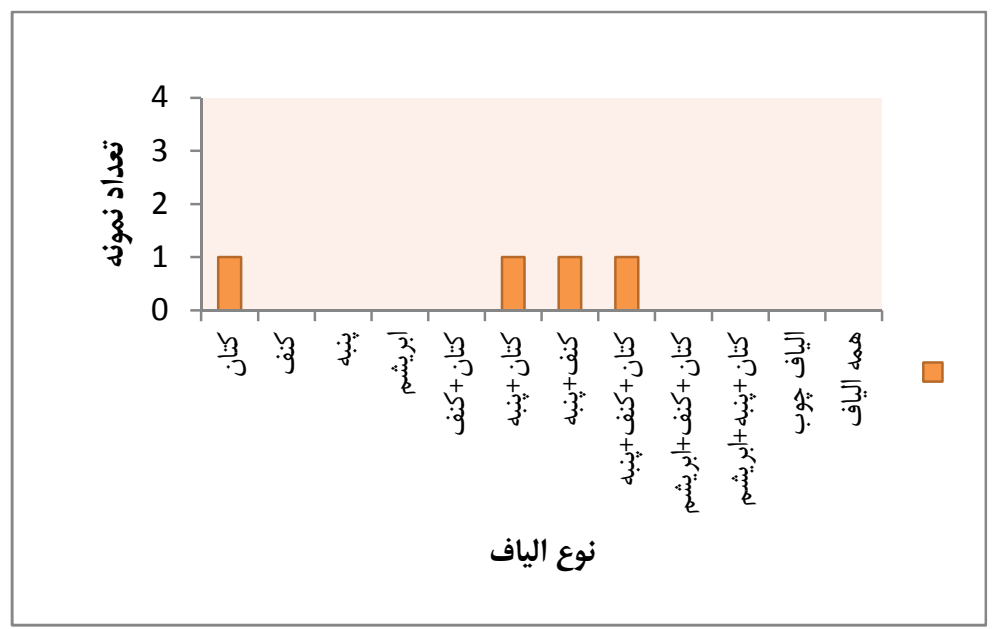

شكل و: نمودار نتايج بهدستآمده از مطالعهى ميكروسكويى الياف نسخ با كتابت نامعلوم 
جدول "ا: خلاصه نتايج بهدستآمده از شناسايى الياف با استفاده از معرفهاى رنكى (يونسى، سوسا، ص. VD)

\begin{tabular}{|c|c|c|c|c|}
\hline نتيجه & سلكر & هرزبرتى & C & شماره \\
\hline خمير كهنه يارجه & قرمز & قرمز - قهوهاى & نارنجى قرمز & K818 \\
\hline خمير كهنه يار خه & قرمز تيره & قرمز & نارنجى تيره & K676 \\
\hline خمير كهنه يارجه & قرمز & قرمز- قهوهاى & نارنجى -قرمز & K597 \\
\hline خمير كهنه پيار جه & قرمز تيره & قهوماى & نارنجى & K1041 \\
\hline خمير كهنه يار خه & قرمز & قرمز & نارنجى - قرمز & K1432 \\
\hline خمير كهنه پيارجه & قرمز & قرمز تيره & قرمز - نارنجى تيره & K1872 \\
\hline خمير كهنه پارجه & قرمز & قرمز - نارنجى & زرد- حنايى & K1144 \\
\hline خمير كهنه يارجه & قرمز & قرمز & قرمز & K413 \\
\hline خمير غير جوبى & 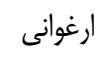 & قرمز & قهوl & K1927 \\
\hline خمير كهنه يارجه & قرمز & قرمز تيره & قرمز - قهوماى & K1980 \\
\hline خمير كهنه يارجه & قرمز & قرمز & قرمز-قهوهاى تيره & K650 \\
\hline خمير كهنه پارجه & قرمز & قرمز & قرمز & K1134 \\
\hline خمير كهنه يارجه & قرمز & قرمز & زرد & K123 \\
\hline خمير كهنه پارجه & قرمز تيره & قرمز-نارنجى & نارنجى & K1672 \\
\hline خمير كهنه پارجه & قرمز & قرمز & نارنجى -قرمز & K156 \\
\hline خمير غير خوبى & ارغوانى & نارنجى تيره & قهوهاى -قرمز & K534 \\
\hline خمير كهنه پارجه & قرمز & نارنجى تيره & حنايى & $\mathrm{K} 1212$ \\
\hline خمير كهنه يارجه & قرمز تيره & قرمز & نارنجى & K1358 \\
\hline خمير كهنه يارجه & قرمز تيره & نارنجى -قرمز & نارنجى & K1179 \\
\hline خمير كهنه يارجه & قرمز & نارنجى & قرمز & K236 \\
\hline خمير كهنه يار خه & قرمز & ارغوانى & قرمز -قهوهاى & U1522 \\
\hline خمير كهنه پارجه & قرمز & نارنجى -قرمز & نارنجى -قرمز & U1497 \\
\hline خمير كهنه پيار جه & قرمز & قرمز & نارنجى & U1476 \\
\hline خمير كهنه يارجه & قرمز & آبى -بنفش & بنفش & U1359 \\
\hline
\end{tabular}

به خوبى سابيده و در دستخاه قرص ساز مخصوص، براى

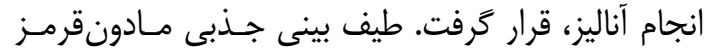

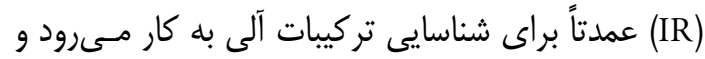

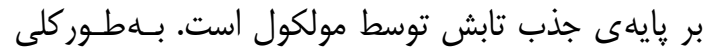
تمامى تركيبات شيميايى، جـذب انتخـابى مشخصى درد درد

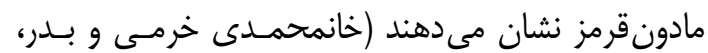

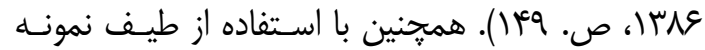

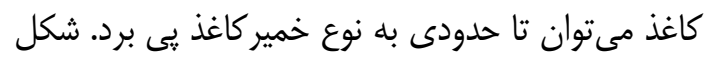

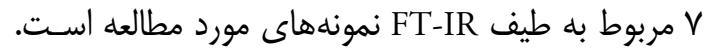

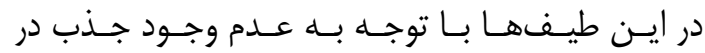

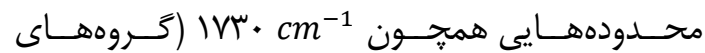
اكسيدشده)، 109 c cm (بهطور كلى بـه كربو كسـيلات نسبت دادهشده)،

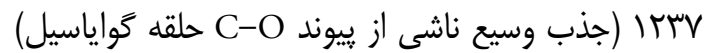

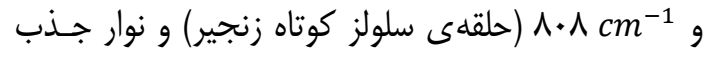

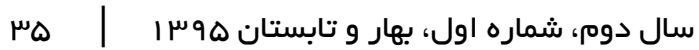

\section{צ- شناسايى الياف به كمك معرفهاى رنكى} راه ديخر براى تعيـين تركيبـات فيبـرى كاغـــ اسـتفاده از معرفهاى رنكى اسـت. معـرفهـاى بكـار رفتـه در ايـن

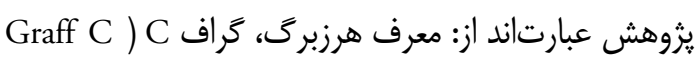

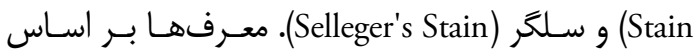

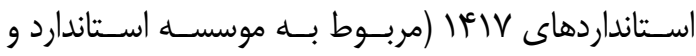
تحقيقات صنعتى ايران) تهيــه و مقايسـهـ رنـــ اليـاف در

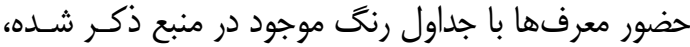

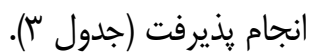

\section{V - شناسايى الياف با استفاده از طيفسنجى

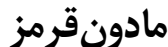
براى انجام اين آزمايش ابتدا نمونهسازى انجـام گرفـت. براى تهيه قرص مورد نظر، هر يك از نمونهها همراه بـاــا

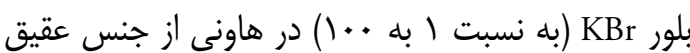




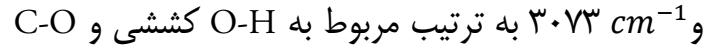

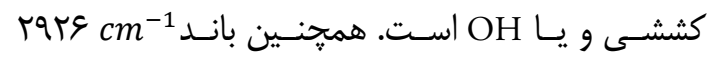

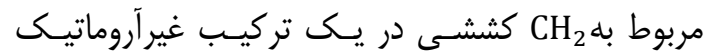

در حدود

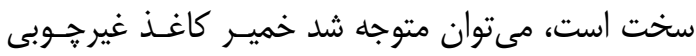

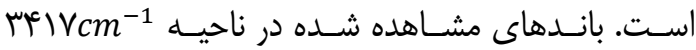

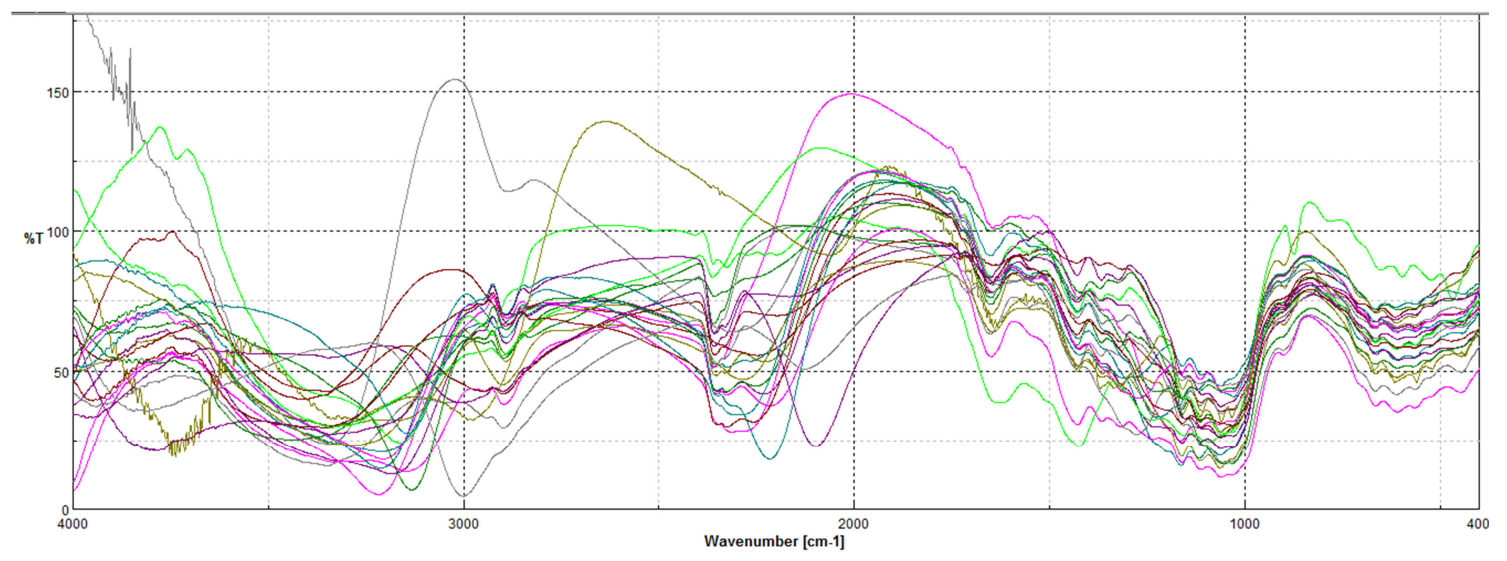

شكلV: طيف FT-IR نمونههاى مورد مطالعه

جدول ‘: خلاصه نتايج حاصل از شناسيى الياف با استفاده از دستخاه طيفسنج مادون قرمز (FT-IR) (اعداد جذبى بصورت حدودى هستند)

\begin{tabular}{|c|c|c|c|c|c|c|c|}
\hline نتيجه احتمالى & $\Lambda+\Lambda c m^{-1}$ & $1 \Delta \Delta+\mathrm{cm}^{-1}$ & $11 \Delta \Lambda c m^{-1}$ & $190+\mathrm{cm}^{-1}$ & $\mathrm{lfr}+\mathrm{cm}^{-1}$ & $\mathrm{IVr}+\mathrm{cm}^{-1}$ & شماره \\
\hline فاقد الياف جوبى & - & + & + & + & + & - & K818 \\
\hline فاقد الياف جوبى & - & - & + & - & + & - & K676 \\
\hline فاقد الياف جوبى & - & - & + & - & + & - & K597 \\
\hline فاقد الياف خوبى & - & - & + & - & + & - & K1041 \\
\hline فاقد الياف خوبى & - & - & + & - & - & - & K1432 \\
\hline فاقد الياف خوبى & - & - & + & - & + & - & K1872 \\
\hline فاقد الياف خوبى & - & - & + & - & + & - & K1144 \\
\hline فاقد الياف خوبى & - & - & + & - & + & - & K413 \\
\hline فاقد الياف جوبى & - & - & - & - & + & - & K1927 \\
\hline فاقد الياف خوبى & - & - & - & - & - & - & K1980 \\
\hline فاقد الياف خوبى & - & - & + & - & + & - & K650 \\
\hline فاقد الياف خوبى & - & - & + & - & + & - & K1134 \\
\hline فاقد الياف خوبى & - & + & + & - & + & - & K123 \\
\hline فاقد الياف جوبى & - & - & + & - & + & - & K1672 \\
\hline فاقد الياف جوبى & - & - & + & - & + & - & K156 \\
\hline فاقد الياف جوبى & - & - & + & - & + & - & K534 \\
\hline فاقد الياف خوبى & - & - & + & - & + & - & K1212 \\
\hline فاقد الياف خوبى & - & - & + & - & + & - & K236 \\
\hline فاقد الياف خوبى & - & - & + & - & - & - & K1358 \\
\hline فاقد الياف خوبى & - & - & + & - & + & - & K1179 \\
\hline فاقد الياف خوبى & - & - & + & - & + & - & U1522 \\
\hline فاقد الياف خوبى & - & - & + & - & + & - & U1497 \\
\hline فاقد الياف جوبى & - & - & + & - & + & - & U1476 \\
\hline فاقد الياف خوبى & - & - & + & - & + & - & U1359 \\
\hline
\end{tabular}


غالب مشاهده شدند. در برخى از منابع به نوع و مواد مورد استفاده در كاغذسازى اشاره شده است: شيلاكن بـاى نئ نيـز

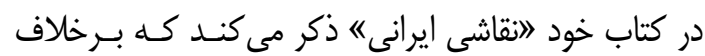

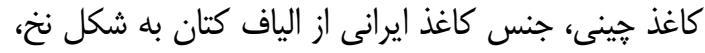

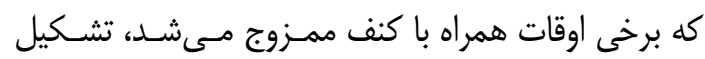

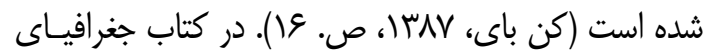
اصفهان، متنى به شرح زير آمده است:

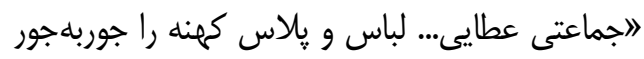

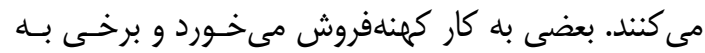

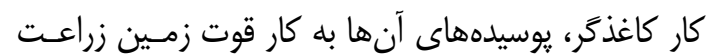

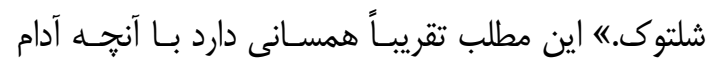
اولئاريوس دربارهى كاغذسازى مرسوم در ايران ديده بـود:

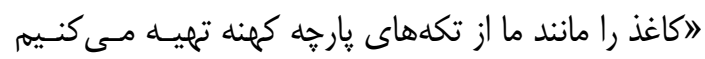
آنان از كتان و يا اكر بايد ظريف و نازك باشـــ از ابريشهم درست مى كننده (افشار، •وسا، ص. هـ).

\section{9- نتيجلكيرى}

با توجه به نتايج بهدستآمده، الياف جوبى در هيج كـدام از

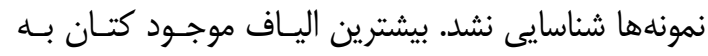
همراه كنـف و يـس از آن كتـان، كنفف و ينبـهـ بـاهم در نمونهها مشاهده شد. نكته قابل توجه در بررسىها، مـوارد

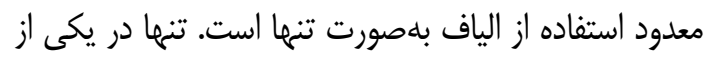

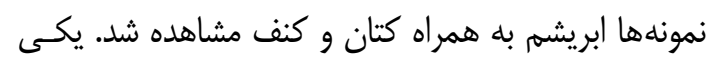
از احتمالات موجود، مى تواند نوع خمير باشد كه احتمالاًا لمداز

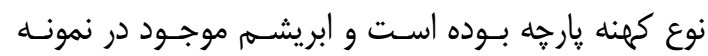

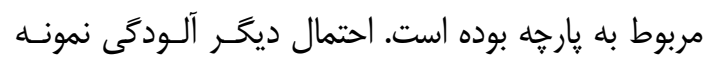
حين ساخت كاغذ اسـت. در ادامهـ برخى از اليـاف مـورد استفاده در كاغذسازى كذشته آورده شده است كه با نتـايج بلهدست آمده همخوانى خوبى را نشان مى دهد. روش ديخـر

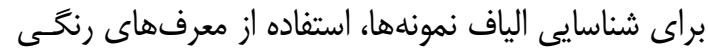

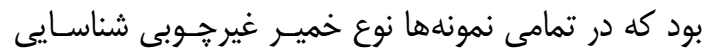

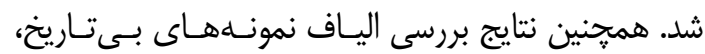
مطابقت خوبى با نمونههاى با تاريخ معلوم نشان داد. ايـن تصن

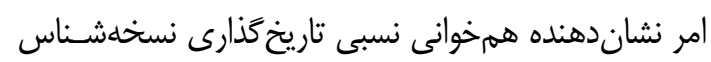

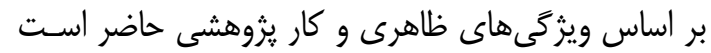

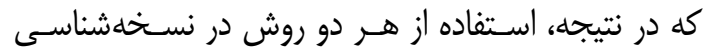

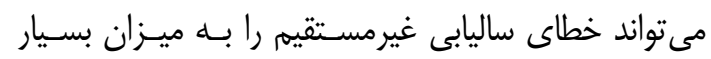

است. باندهاى موجود در ترتيب مربوط به C-C كششى در يك تركيب حلقـوى و

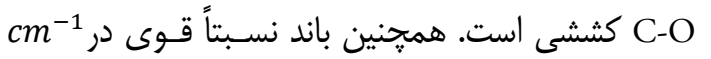

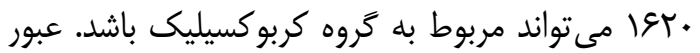

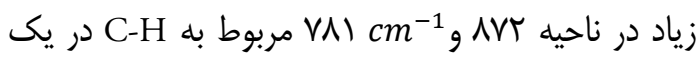

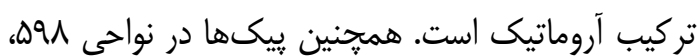

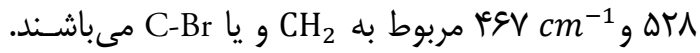

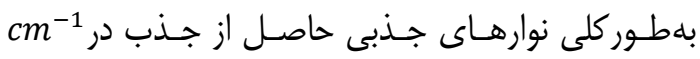

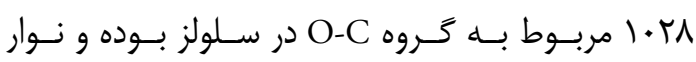

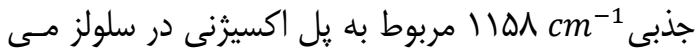

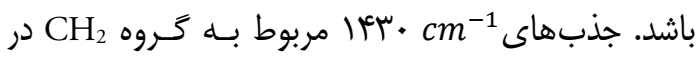
زنجيره يلى ساكاريدهاست.

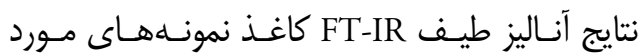
مطالعه (با توجه به رنخى طيف) در جدول ع آمده است.

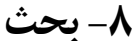

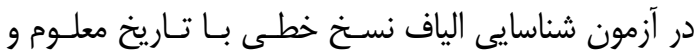

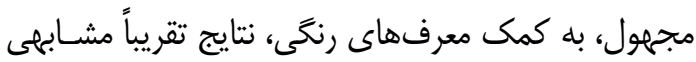

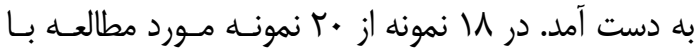

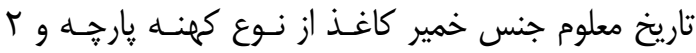

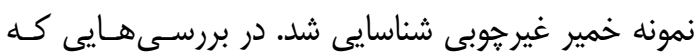

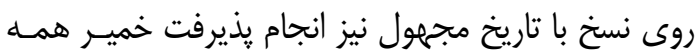

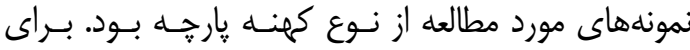
اطمينان بيشتر از نتايج بهدست آمده بررسى هايى با استفاده از آناليز FT-IR انجام كَرفت كه بــا اسـتفاده از ايـن آنـاليز نتايج مشابهى با دو روش ذكر شده به دست آمد. البته بايد

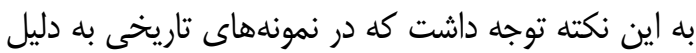
محدوديت در نمونهبردارى امكان خطا در برخى از جزئيات

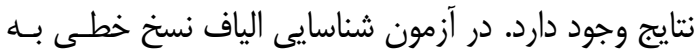

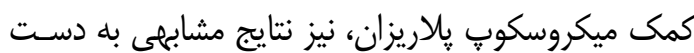
آمد. در نمونه هاى با تاريخ معلوم، كتان، كنف، و ينبـهـ بــهـ

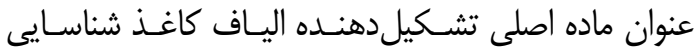
شدند. البته در برخى از نمونهها ميزان اندكى برك، كاه و

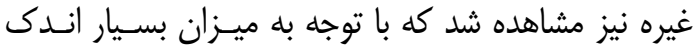

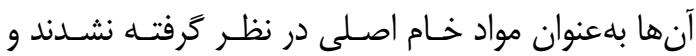

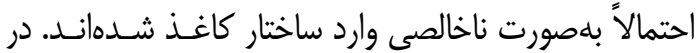

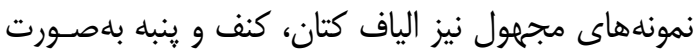




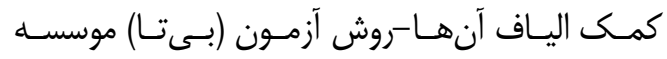

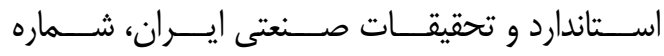

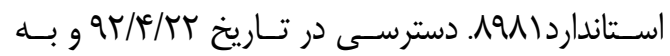

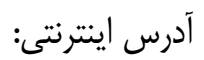

www.isiri.gov.ir/portal/files/std/8981

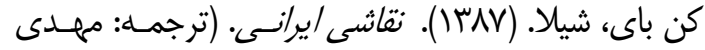
حسينى). تهران: دانشكاه هنر.

نيكسرشت سيخارودى، محمدرضا، صفدرى، وحيـــ رضـا،

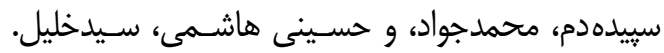

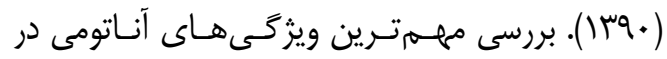

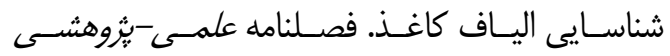

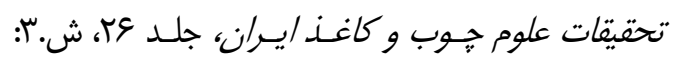

. $\left.\Delta F T^{\mu}-\Delta\right)^{C} \Delta$

يونسى، بهاره. (سوج(1). تحليل هاى باستانسنجى الياف و

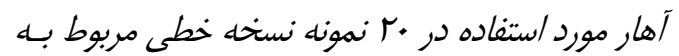

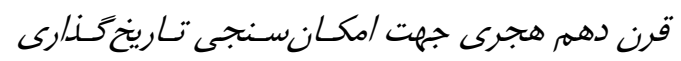

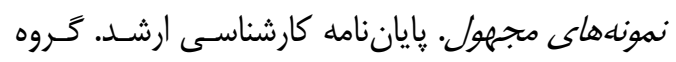

باستان سنجى و مرمت. دانشـكده هنرهـاى كـاربردى.

$$
\text { دانشكاه هنر اسلامى تبريز. }
$$

\section{منابع لاتين}

Agrawal, O. P., \& Barkeshli, M. (1997). Conservation of Books, Manuscripts, and Paper Documents. INTACH.

Haugan, E., \& Holst, B. (2013). Flax look-alikes: Pitfalls of ancient plant fibre identification. Archaeometry, 56(6), 951-960.

Isenberg, I. H. (1958). Pulp and paper microscopy, 3rd ed. Institute of Paper Chemistry, Appleton, WI.

McBride, C. (2002). A pigment particle \& fiber atlas for paper conservators. Cornell University Available at 12/10/2013 at: www.library.cornell.edu/preservation/publicatio ns/mcbride.html

Shi, J. L., \& Li, T. (2013). Technical investigation of 15th and 19th century Chinese paper currencies: Fiber use and pigment identification. Journal of Raman Spectroscopy, 44(6), 892-898.

TAPPI. (2000). TAPPI standards and suggested methods, T 401om-93. Fiber analysis of paper and paperboard. Test Methods TAPPI press, Atlanta, Ga.

Yum, H., Singer, B. W., \& Bacon, A. (2009). Coniferous wood pulp in traditional Korean paper between the 15th and 18th centuries AD. Archaeometry, 51(3), 467-479.
زيادى كاهش دهد. لازم به ذكر اسـت بـراى رسـيدن بـهـ

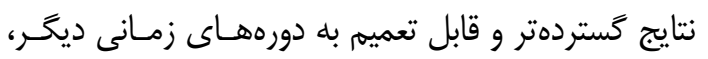

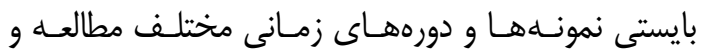

$$
\text { بررسى شوند. }
$$

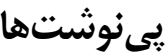

I. تمامى اطلاعات اين جدول بر اسـاس نظـر كارشـناس

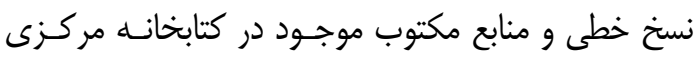

$$
\text { تبريز آورده شده است. }
$$

I. منابع مورد استفاده بـراى شناسـيى اليـاف: Isenberg

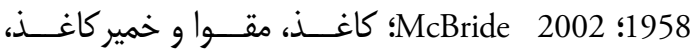

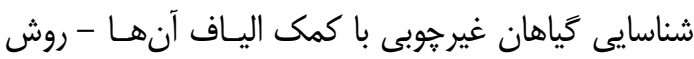

$$
\text { آزمون (بى تانا). }
$$

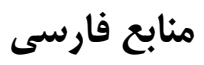

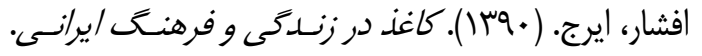
تهران: مركز يزوهشى ميراث مكتوب.

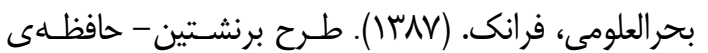

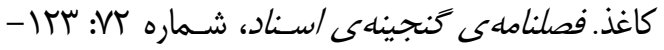

$.1 \%$.

بهادرى، رويا، و بحرالعلومى، فرانك. (•وسا). بررسىهـاى

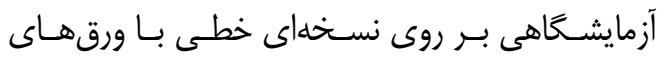

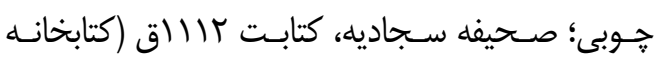
مجلـس شـوراى اسـلامى، ش شعال)، نامـه بهارستان،

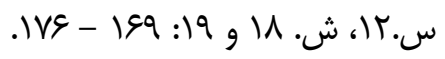

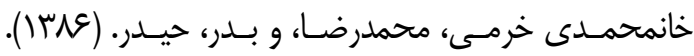
شيمى تجزيه دستخاهى. قزوين: انتشارات دانشخاه بين الملى امام خمينى(ره).

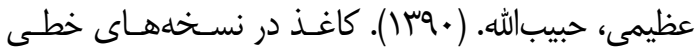

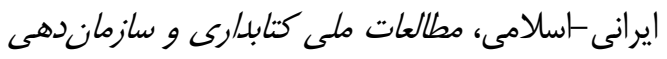

$$
\text { اطلاعات، ش. M. M. }
$$

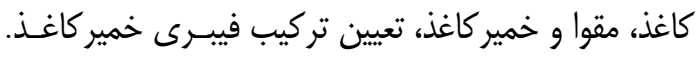

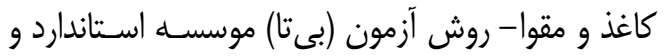

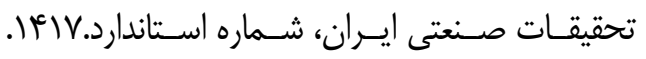

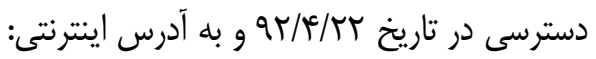
www.isiri.gov.ir/portal/files/std/1417

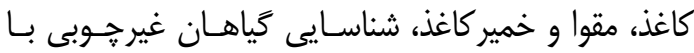

